\begin{tabular}{lc}
\hline CURRENT & ISSN: 0973-4929, Vol. 12, №. (2) 2017, Pg. 339-344 \\
WORLD & Current World Environment
\end{tabular}

ENVIRONMENT Journal Website: www.cwejournal.org

\title{
Biomass Allocation and Carbon Stock in Elm (Ulmus Wallichiana Planch) Plantation
}

\author{
SHABIR AHMAD RATHER ${ }^{1 *}$, K.N. QAISAR ${ }^{1}$, SABEENA NABI ${ }^{1}$, \\ R. BANYAL ${ }^{2}$, P.A. KHAN ${ }^{1}$ and M.A. ISLAM ${ }^{1}$
}

${ }^{1}$ Faculty of Forestry, SKUAST-K, Benhama, Ganderbal-191201 (J\&K), India.

${ }^{2}$ Central Soil Salinity Research Institute, Karnal, Haryana, India.

\begin{abstract}
The present investigation was conducted on a 22 year old Elm plantation established at Wadura campus of SKUAST-Kashmir. Four diameter classes viz., D1 $(5-10 \mathrm{~cm}), \mathrm{D} 2(10-15 \mathrm{~cm}), \mathrm{D} 3(15-20 \mathrm{~cm})$ and D4 $(>20 \mathrm{~cm})$ were stratified from the plantation and 24 trees ( 6 from each diameter class) were randomly selected and felled in the year 2015. The growth parameters of the trees increased with increase in the diameter class. The maximum height, dbh, basal area and stem volume were $14.98 \mathrm{~m}, 23.77 \mathrm{~cm}, 0.044 \mathrm{~m} 2$ and $0.400 \mathrm{~m} 3$, respectively. Biomass per tree of all tree components viz., stem, branches, foliage and roots showed significant increase with increase in the diameter of the trees. The total biomass, carbon stock and carbon dioxide equivalent increased from lower to higher diameter classes. The highest values observed for these parameters were $475.54 \mathrm{~kg} /$ tree (fresh), $148.59 \mathrm{~kg} /$ tree and $543.82 \mathrm{~kg} /$ tree, respectively under D4 diameter class. The biomass allocation coefficient of branch and root (BACb and BACr) attained higher values in lower diameter classes. The maximum and minimum values of these coefficients were 0.158 and $0.085 ; 0.298$ and 0.278 , respectively under D1 and D4 diameter classes. The size of trees did not produce significant effect on the biomass allocation coefficient of foliage (BACf). The diameter of the trees produced non-significant difference in the growth efficiency (GE) of different tree components.
\end{abstract}

\section{Introduction}

Ulmus wallichiana, the Himalayan Elm, is a fast growing tree species which grows in Himalayas from Kashmir to Uttarakhand between the elevations of 900 to $3000 \mathrm{~m}$ amsl. The Himalayan Elm grows to a height of about $30 \mathrm{~m}$, with a broad crown having several ascending branches. The bark of the trunk is vertically furrowed and grayish brown in colour. Before the introduction of populous deltoides, it was the most cultivated tree species of the Kashmir valley

CONTACT SHABIR AHMAD RATHER sshab32@gmail.com 9 Faculty of Forestry, SKUAST-K, Benhama, Ganderbal-191201 (J\&K), India.

(C) 2017 The Author(s). Published by Enviro Research Publishers

This is an 6 Open Access article licensed under a Creative Commons Attribution-NonCommercial-ShareAlike 4.0 International License (https://creativecommons.org/licenses/by-nc-sa/4.0/ ), which permits unrestricted NonCommercial use, distribution, and reproduction in any medium, provided the original work is properly cited.

To link to this article: http://dx.doi.org/10.12944/CWE.12.2.17 
having multifarious uses viz., light construction, fuelwood, packing cases, furniture and fodder for cattle (Phartyal et al., 2003).

Ever increasing atmospheric $\mathrm{CO}_{2}$ concentration and its management is a serious concern confronting the world today. The concentration of $\mathrm{CO}_{2}$ in the atmosphere can be reduced either by limiting emissions or by taking $\mathrm{CO}_{2}$ out from the atmosphere and stored in the terrestrial, oceanic or aquatic ecosystems. Forestry practices have the significant potential to considerably reduce the global flux $\mathrm{CO}_{2}$ into the atmosphere. In the past forestry plantations only had a small contribution to the total balance of terrestrial carbon but they have been recognized to play a more significant role in the future mitigation of climate change on account of their potential to absorb and store carbon (Canadell et al., 2007). According to FAO, the world's forest plantation accounted for less than $7 \%$ or 264 million ha of total forest area, in which $78 \%$ are productive and $22 \%$ are protective. The world's forests are estimated to store 289 gigatonnes (Gt) of carbon $(\mathrm{C})$ in their biomass alone and on account of deforestation the annual decrease in the carbon storage was about 0.5 Gt during the period 20052010 (FAO, 2010). The total carbon storage in forest plantations now-a-days is about $11.8 \mathrm{Gt}$ with an increase of $0.178 \mathrm{Gt}$ per year. Furthermore, the United Nations Framework Convention on Climate Change has recognized the significance of plantation forestry as a greenhouse gas mitigation option, as well as the need to monitor, preserve, and enhance terrestrial carbon stocks (Updegraff et al., 2004). Due to fast growth and better silvicultural practices and management, plantation forestry has an edge over natural forests. Projections of the International Centre for Research in Agroforestry suggest that significant funds could potentially be available to finance sustainable rural development and adaptation to climate change, as the carbon market may exceed US \$1 trillion by 2025 (ICRAF, 2009).

\section{Material and Methods}

The study was carried out on a 22-year old plantation of Elm located at an altitude of $1510 \mathrm{~m}$ amsl in the Faculty of Agriculture, SKUAST-K, Wadura, Sopore (J\&K). The plantation falls in the temperate zone and lies at $3403^{\circ} \mathrm{N}$ latitude and $7405^{\circ} \mathrm{E}$ longitude.
The trees in the plantation were stratified into four diameter classes i.e., D1:5-10 cm, D2: 10-15 cm, D3: $15-20 \mathrm{~cm}$ and D4: $>20 \mathrm{~cm}$. Twenty four trees were randomly selected from the plantation (six from each diameter class) and harvested during the year 2015 for biomass and carbon estimation. These trees were measured for their growth parameters using standard biometric methods. The allocation of biomass to different tree components, growth efficiency, carbon stock and carbon dioxide equivalent were estimated as follows:

Stem biomass (Bs) $(\mathrm{kg})$ : The main stem of each tree was cut into logs of different lengths. Fresh weight of these logs was recorded with the help of mechanical weighing balance and summed up to give stem biomass. Sample discs from each log were taken for dry weight determination.

Branch biomass $(\mathrm{Bb})(\mathrm{kg})$ : Branches from each tree were cut and weighed in the field for estimation of branch biomass. The branch samples were collected from the trees for dry weight determination.

Foliage biomass (Bf) (kg): The foliage biomass was estimated by collecting the foliage from each felled tree and weighing in the field. The samples of foliage from the trees were taken for estimation of dry matter.

Root biomass $(\mathrm{Br})(\mathrm{kg})$ : The root biomass was calculated by using simple default value of $25 \%$ (for hardwood species) of the above ground biomass as recommended by IPCC (2006).

Total tree biomass $(\mathrm{Bt})(\mathrm{kg})$ : The total tree biomass was calculated as the sum of stem, branch, foliage and root biomass.

Biomass allocation coefficients (BACs): Biomass allocation coefficients were calculated as the ratio between a particular biomass component increment and stem biomass increment.

Growth efficiency (GE): Growth efficiency was estimated as the ratio of relevant biomass component increment to standing foliage biomass.

Carbon stock $(\mathrm{kg})$ : The biomass value was converted to carbon stock using 0.5 default value (IPCC, 2006).

Carbon dioxide equivalent $(\mathrm{CO} 2 \mathrm{e})(\mathrm{kg})$ : The carbon dioxide equivalent was calculated as per the following equation:

Carbon dioxide equivalent $=$ Carbon stock $\times 3.66$ 


\section{Statistical Analysis}

The data collected was subjected to statistical analysis using general linear model procedure of SPSS Statistic version (17.0).

\section{Results and Discussion}

The growth parameters of the trees increased with increase in the diameter class (Table-1). The maximum values recorded for height, $\mathrm{dbh}$, basal area and stem volume were $14.98 \mathrm{~m}, 23.77 \mathrm{~cm}, 0.005 \mathrm{~m}^{2}$ and $0.400 \mathrm{~m}^{3}$ under diameter class $\mathrm{D}_{4}$ and minimum $07.67 \mathrm{~m}, 08.08 \mathrm{~cm}, 0.044 \mathrm{~m}^{2}$ and $0.027 \mathrm{~m}^{3}$ under $\mathrm{D}_{1}$ class, respectively. These results are in conformity with the findings of Bohre et al., (2013) and Arifin et al., (2008). This can be attributed to more absorption of nutrients and light by the dominant trees present in the plantation. Yeboah et al., (2014) found strong correlation between dbh and total main stem volume of the trees. Also, Islam and Masoodi (2007) reported strong positive correlation between $\mathrm{dbh}$, height and stem volume in Elm. The pattern of biomass allocation in different tree components, carbon stock and carbon dioxide equivalent are depicted in the Table-2 and 3. The critical appraisal of the data revealed that stem biomass gradually increased with increase in the size of trees attaining highest values of $368.28 \mathrm{~kg} /$ tree (fresh) and $212.22 \mathrm{~kg} /$ tree (dry) in $\mathrm{D}_{4}$ diameter class. The lowest values of $23.50 \mathrm{~kg} /$ tree (fresh) and $12.37 \mathrm{~kg} /$ tree (dry) were recorded under diameter class $D_{1}$. The results corroborate the observations of Wagay (2012) and Mitra et al. (2011). The branch biomass also showed perpetual increase with the increase in diameter of trees. The maximum branch biomass of $34.95 \mathrm{~kg} /$ tree (fresh) and $18.98 \mathrm{~kg} /$ tree (dry) was produced by diameter class $D_{4}$ whereas, the minimum of $03.34 \mathrm{~kg} /$ tree (fresh) and $01.98 \mathrm{~kg} /$ tree (dry) was observed under $D_{1}$ diameter class. The branch biomass depends on the average number of branches on the trees.
These results are in agreement with the findings of Pande et al., (1987) and Singh et al., (1994). There was an increase in foliage biomass from lower to higher diameter classes recording highest values of $16.20 \mathrm{~kg} /$ tree (fresh) and $6.54 \mathrm{~kg} /$ tree (dry) for diameter class $D_{4}$. The reason for such a pattern is the occurrence of more number of branches in the large sized trees than the smaller ones. Similar results have been obtained by Wagay (2012) in Populus deltoides. The root biomass was found to increase with increase in the diameter of the trees. The maximum and minimum root biomass of $105.11 \mathrm{~kg} /$ tree (fresh) and $07.07 \mathrm{~kg} /$ tree (fresh) were observed under diameter classes D4 and D1, respectively. This is in conformity with the results of Saralach (1994) in Eucalyptus. These results of biomass are also well supported by Morhart et al., (2013) who reported strong correlation between dry weight of different tree components and $\mathrm{dbh}$ in a poplar clone.

The total dry biomass, carbon stock and carbon dioxide equivalent increased from lower to higher diameter classes. The highest values for these parameters were $297.17 \mathrm{~kg} /$ tree, $148.59 \mathrm{~kg} /$ tree and $543.82 \mathrm{~kg} / \mathrm{tree}$, respectively under D4 diameter class and the lowest values of $18.57 \mathrm{~kg} /$ tree, $09.29 \mathrm{~kg} /$ tree and $33.99 \mathrm{~kg} /$ tree, respectively under $\mathrm{D}_{1}$ diameter class. This increased production of biomass and storage of carbon can be explained by the increased absorption of light, water and nutrients by the large trees. Our findings corroborate with results of Wagay (2012) in Populus deltoides and Wani et al., (2014) in Ulmus wallichiana.

The biomass allocation coefficients of branch and root (BACb and BACr) attained higher values in lower diameter classes (Table-4). The maximum and minimum values of these coefficients were 0.158 and $0.085 ; 0.298$ and 0.278 , respectively under $D_{1}$ and $\mathrm{D}_{4}$ diameter classes. This trend can be explained by

Table 1: Growth parameters of 22 year old UImus wallichiana trees.

\begin{tabular}{lllll}
\hline $\begin{array}{l}\text { Diameter class } \\
(\mathbf{c m})\end{array}$ & $\begin{array}{l}\text { Height } \\
(\mathbf{m})\end{array}$ & $\begin{array}{l}\mathbf{d b h} \\
\mathbf{( c m})\end{array}$ & $\begin{array}{l}\text { Basal area } \\
\left(\mathbf{m}^{2}\right)\end{array}$ & $\begin{array}{l}\text { Stem volume } \\
\left(\mathbf{m}^{3}\right)\end{array}$ \\
\hline $\mathrm{D}_{1}(5-10)$ & 07.67 & 08.08 & 0.005 & 0.027 \\
$\mathrm{D}_{2}(10-15)$ & 11.25 & 13.06 & 0.013 & 0.093 \\
$\mathrm{D}_{3}(15-20)$ & 13.57 & 16.95 & 0.023 & 0.187 \\
$\mathrm{D}_{4}(>20)$ & 14.98 & 23.77 & 0.044 & 0.400 \\
$\mathrm{CD}(0.05)$ & 1.52 & 1.78 & 0.004 & 0.064 \\
\hline
\end{tabular}


Table 2: Pattern of biomass (fresh) allocation to different tree components of 22 year old Ulmus wallichiana in different diameter classes.

\begin{tabular}{llllll}
\hline $\begin{array}{l}\text { Diameter } \\
\text { class } \\
(\mathbf{c m})\end{array}$ & $\begin{array}{l}\text { Stem } \\
\text { biomass } \\
\text { (fresh) } \\
\mathbf{( k g / t r e e )}\end{array}$ & $\begin{array}{l}\text { Branch } \\
\text { biomass } \\
\text { (fresh) } \\
\mathbf{( k g / t r e e )}\end{array}$ & $\begin{array}{l}\text { Foliage } \\
\text { biomass } \\
\text { (fresh) } \\
\mathbf{( k g / t r e e )}\end{array}$ & $\begin{array}{l}\text { Root } \\
\text { biomass } \\
\text { (fresh) } \\
(\mathbf{k g} / \text { tree) }\end{array}$ & $\begin{array}{l}\text { Total tree } \\
\text { biomass } \\
\text { (fresh) } \\
\text { (kg/tree) }\end{array}$ \\
\hline $\mathrm{D}_{1}(5-10)$ & 23.50 & 03.34 & 01.45 & 07.07 & 35.36 \\
$\mathrm{D}_{2}(10-15)$ & 79.48 & 09.27 & 04.07 & 23.20 & 116.02 \\
$\mathrm{D}_{3}(15-20)$ & 137.33 & 19.68 & 08.75 & 41.44 & 207.20 \\
$\mathrm{D}_{4}(>20)$ & 369.28 & 34.95 & 16.20 & 105.11 & 475.54 \\
$\mathrm{CD}(0.05)$ & 56.44 & 08.40 & 03.70 & 16.44 & 89.08 \\
\hline
\end{tabular}

Table 3: Pattern of biomass (dry) allocation to different tree components of 22 year old Ulmus wallichiana in different diameter classes.

\begin{tabular}{|c|c|c|c|c|c|c|c|}
\hline $\begin{array}{l}\text { Diameter } \\
\text { class } \\
\text { (cm) }\end{array}$ & $\begin{array}{l}\text { Stem } \\
\text { biomass } \\
\text { (dry) } \\
\text { (kg/tree) }\end{array}$ & $\begin{array}{l}\text { Branch } \\
\text { biomass } \\
\text { (dry) } \\
\text { (kg/tree) }\end{array}$ & $\begin{array}{l}\text { Foliage } \\
\text { biomass } \\
\text { (dry) } \\
\text { (kg/tree) }\end{array}$ & $\begin{array}{l}\text { Root } \\
\text { biomass } \\
\text { (dry) } \\
\text { (kg/tree) }\end{array}$ & $\begin{array}{l}\text { Total tree } \\
\text { biomass } \\
\text { (dry) } \\
\text { (kg/tree) }\end{array}$ & $\begin{array}{l}\text { Carbon } \\
\text { stock } \\
\text { (kg/tree) }\end{array}$ & $\begin{array}{l}\mathrm{CO}_{2} \mathrm{e} \\
(\mathrm{kg} / \text { tree })\end{array}$ \\
\hline$D_{1}(5-10)$ & 12.37 & 01.98 & 0.51 & 03.71 & 18.57 & 09.29 & 33.99 \\
\hline $\mathrm{D}_{2}(10-15)$ & 42.47 & 05.29 & 1.51 & 12.25 & 61.52 & 30.78 & 112.66 \\
\hline$D_{3}(15-20)$ & 75.65 & 10.83 & 3.35 & 22.46 & 112.29 & 56.14 & 205.46 \\
\hline$D_{4}(>20)$ & 212.22 & 18.98 & 6.54 & 59.43 & 297.17 & 148.59 & 543.82 \\
\hline $\mathrm{CD}(0.05)$ & 31.54 & 04.66 & 01.52 & 09.08 & 46.04 & 23.02 & 84.26 \\
\hline
\end{tabular}

$\mathrm{CO}_{2} \mathrm{e}=$ Carbon dioxide equivalent

the increase in the stem biomass increment from lower diameter to higher diameter classes. The size of trees did not produce significant effect on the biomass allocation coefficient of foliage (BACf). This insignificant difference can be ascribed to higher foliage increments in the large trees. Irrespective of size of the trees, the biomass allocation coefficients followed the order $\mathrm{BACr}>\mathrm{BACb}>$ BACf. Wagay (2012) also found more allocation of biomass in roots as compared to branches and leaves in Populus deltoides. Moreover, Pathak et al., (2015) and Sharma et al., (2014) reported variation in biomass allocation to different components in some species of bamboo.
The diameter of the trees produced insignificant difference in the growth efficiency (GE) of different tree components (Table-4). Kaufman and Ryan (1986) pointed out that suppressed and overtopped trees can reach GE values almost as high as the dominant individuals, mainly because they tend to maintain smaller mass of foliage relative to the stem. Irrespective of the diameter class, the highest growth efficiency was observed in stem (1.473) followed by roots $(0.421)$ and branches $(0.169)$. This trend can be attributed to more allocation of biomass in stem followed by roots and branches. 
Table 4: Biomass allocation coefficients and growth efficiency of different tree components of 22 year old Ulmus wallichiana in different diameter classes

\begin{tabular}{lllllll}
\hline $\begin{array}{l}\text { Diameter class } \\
(\mathbf{c m})\end{array}$ & BACb & BACf & BACr & GEs & GEb & GEr \\
\hline $\mathrm{D}_{1}(5-10)$ & 0.158 & 0.040 & 0.298 & 1.261 & 0.192 & 0.373 \\
$\mathrm{D}_{2}(10-15)$ & 0.127 & 0.035 & 0.289 & 1.416 & 0.178 & 0.408 \\
$\mathrm{D}_{3}(15-20)$ & 0.138 & 0.043 & 0.295 & 1.134 & 0.149 & 0.332 \\
$\mathrm{D}_{4}(>20)$ & 0.085 & 0.030 & 0.278 & 2.084 & 0.158 & 0.572 \\
Mean & 0.127 & 0.037 & 0.290 & 1.473 & 0.169 & 0.421 \\
CD (0.05) & 0.032 & NS & 0.010 & NS & NS & NS \\
\hline
\end{tabular}

$\mathrm{BACb}, \mathrm{BACf}$ and $\mathrm{BACr}=$ Biomass allocation coefficients of branches, foliage and roots GEs, GEb and GEr = Growth efficiency of stem, branches and roots

\section{References}

1. Arifin, A., Tanaka, S., Jusop, S., Majid, N.M., Ibrahim, Z., Wasli, M.E., \& Sakuri, K., Assessment on soil fertility status and growth performance of planted Dipterocarp species in peninsular Malaysia. Journal of Applied Science, 8: 3795-3805 (2008).

2. Bohre, P., Chaubey, O.P., \& Singhal, P.K., Biomass accumulation and carbon sequestration in Tectona grandis Linn. f. and Gmelina arborea Roxb. International Journal of Bio-Science and Bio-Technology, 5(3): 153-174 (2013).

3. Canadell, J.G., Kirschbaum, M.U.F., Kurz, W.A., Sanz, M.J., Schlamadinger, B., \& Yamagata, Y., Factoring out natural and indirect human effects on terrestrial carbon sources and sinks. Environmental Science and Policy, 10: 370-384 (2007).

4. FAO., Global Forest Resources Assessment. FAO Forestry Paper 163. Rome (2010).

5. ICRAF., Transforming lives and landscapes through agroforestry science (Medium Term Plan 2010-2012). Nairobi, Kenya: World Agroforestry Centre (2009).

6. IPCC., Task force on national greenhouse gas inventories. In: IPCC Guidelines for National Greenhouse Gas Inventories. (Eds. H.S. Eggleston, L. Buendia, K. Miwa, T. Ngara and K. Tanabe). IGES, Japan pp. 4.1-4.83 (2006).
7. Islam, M.A., \& Masoodi, N.A., Growth performance and biomass productivity of a 9-year old Elm (Ulmus wallichiana) stand in Kashmir valley. SKUAST Journal of Research, 9: 191-197 (2007).

8. Kaufmann, M.R., \& Ryan, M.G., Physiographic, stand, and environmental effects on individual tree growth and growth efficiency in subalpine forests. Tree Physiology, 2: 47-59 (1986).

9. Mitra, A., Sengupta, K., \& Banerjee, K., Standing biomass and carbon storage of above-ground structures in dominant mangrove trees in Sundarbans. Forest Ecology and Management, 261(7): 13251335 (2011).

10. Morhart, C., Sheppard, J., \& Spiecker, H., Above ground leafless woody biomass and nutrient content within different compartments of a P. maximowicii $\times$ P. trichocarpa Poplar clone. Forests, 4: 471-487 (2013).

11. Pande, M.C., Tandon, V.N., \& Rawat, H.S., Organic matter production and distribution of nutrients in Eucalyptus hybrid plantation ecosystems in Karnataka. Indian Forester, 113(11): 713-724 (1987).

12. Pathak, P.K., Kumar, H., Kumari, G., \& Bilyaminu, H., Biomass production potential in different species of bamboo in Central Uttar Pradesh. The Ecoscan, 10(1): 41-43 (2015).

13. Phartyal, S., Thapliyal, J., Nayal, J., \& Joshi, 
G., Seed storage physiology of Himalayan Elm (Ulmus wallichiana): An endangered tree species. Seed Science and Technology, Vol. 31, International Seed Testing Association, Bassersdorf, Switzerland (2003).

14. Saralach, S.H., Nutrient dynamics and biomass production potential of Eucalyptus tereticornis Smith in high density short rotation systems. M.Sc. Thesis, Dr.Y.S. Parmar University of Horticulture and Forestry. Solan (H.P.) p. 99 (1994).

15. Sharma, A., Shahi, C., Bargali, K., Bargali, S.S., \& Rawat, Y.S., Biomass and carbon stock of Drepanostachyum falcatum (Nees) associated with oak forests at and around Nainital. The Ecoscan, 8(1\&2): 105-108 (2014).

16. Singh, S.P., Adhikari, B.S., \& Zobel, D.B., Biomass productivity, leaf longevity and plant structures in central Himalayas. Ecological Monographs, 64(4): 40-421 (1994).
17. Updegraff, K., Baughman, M.J., \& Taff, S.J., Environmental benefits of cropland conversion to hybrid poplar: economic and policy considerations. Biomass Bioenergy, 27: 411-428 (2004).

18. Wagay, S.A., Biomass production, soil nutrient status and construction of volume table of poplar (Populus deltoides, Bartr.) plantation under rain fed conditions. Sher-e-Kashmir University of Agricultural Sciences and Technology of Kashmir p. 59 (2012).

19. Wani, N.R., Qaisar, K.N., \& Khan, P.A., Biomass and carbon allocation in different components of Ulmus wallichiana (elm): an endangered tree species of Kashmir valley. International Journal of Pharma and Bio Sciences, 5(1): (B) 860-872 (2014).

20. Yeboah, D., Burton, A. J., Storer, A.J., \& Frimpong, E.O., Variation in wood density and carbon content of tropical plantation tree species from Ghana. New Forests, 45: 35-52 (2014). 